\title{
A critical review of physical activity figures for comparison studies using IPAQ surveys and accelerometer measurements
}

\author{
Józef Bergier \\ Pope John Paul II State School of Higher Education in Biala Podlaska, Poland
}

\begin{abstract}
Determining physical activity requires the use of such widely recognised assessment methods as the International Physical Activity Questionnaire (IPAQ) and accelerometers. This study reviews national and international research that used these tools in the years 2007-2016 for assessing physical activity in school children. Our analysis discovered higher levels of self-reported physical activity when the IPAQ version with the longer questionnaire was employed. The metabolic equivalent task (MET)-minutes/ week figures, obtained from the long and short questionnaire versions, showed very large disparities, which should in future serve as a signalling mechanism, so that researchers have a better understanding of how this assessment instrument is to be used. In the author's opinion, physical activity in young people will be assessed more objectively when both these tools are employed simultaneously.
\end{abstract}

KEY WORDS: physical activity, adolescents/youth, IPAQ, accelerometers, literature review.

ADDRESS FOR CORRESPONDENCE: Józef Bergier, Pope John Paul II State School of Higher Education, 95/97 Sidorska Street, 21-500 Biala Podlaska, Poland, e-mail: rektor@pswbp.pl

\section{INTRODUCTION}

Regular physical activity is universally recognised as one of the most important health-promoting behaviours. Its pro-health benefits have been proved by a plethora of studies [1-11]. As part of pro-health behaviour, levels of physical activity require constant monitoring. In recent years, a key instrument in surveying physical activity among adolescents has been the International Physical Activity Questionnaire (IPAQ), featuring both long and short questionnaire versions, along with the use of various types of accelerometers. Diverse questionnaires have been used to assess physical activity among schoolchildren and adolescents, along with other social groups, and this has prompted many scientists working on this issue to develop a new, more objective tool for the purpose, namely the IPAQ, in both its long and short questionnaire versions [12]. Indeed, many countries have adapted the original version to suit their particular local conditions, thereby allowing comparative studies to be performed concerning levels of young people's physical activity on different continents. It should be emphasised that the
IPAQ method expresses physical activity in measurable units of metabolic equivalent task (MET)-minutes/week (metabolic equivalent of task), making it possible to categorise tested subjects according to one of three levels of physical activity: high/vigorous (over $3000 \mathrm{MET}$ ), moderate (600-3000 MET) or low (up to $600 \mathrm{MET}$ ). Physical activity in units of MET-minutes/week is calculated by multiplying the metabolic rate for a specific physical activity (i.e. a given type of exercise) by the number of days/ weeks it is performed, relative to mean resting oxygen consumption (i.e. $3.5 \mathrm{ml} \mathrm{O}_{2} / \mathrm{kg}$ of body weight per minute) [13]. The long version of the questionnaire is more detailed and includes questions on physical activities performed at work or during study, during transportation to and from the same, while doing housework, enjoying leisure time and sports, as well as time spent sedentary on weekdays and at weekends. The shorter, simplified version focuses on assessing physical activity in all its forms, divided into three levels of exertion: vigorous/intense, moderate, walking and sitting, but only on weekdays (i.e. excluding Saturdays and Sundays). Since the questionna- 
ires differ to some extent, as this brief description shows, it is worthwhile comparing the results of the long and short versions. It may be assumed that the longer version is used when very detailed analyses are required, e.g. for planning a policy or intervention, whereas the shorter version is used whenever the physical activities of different populations need to be compared within one, or between more than one country [14].

\section{SUMMARY OF FINDINGS}

In line with suggestions made in relevant publications $[14,15]$, the longer IPAQ version gives somewhat higher estimates of physical activities than the short version when these are separately compared.

\section{THE FINDINGS FROM THE SHORT IPAQ QUESTIONNAIRE}

It should be remembered that this focuses on three types of total physical activity according to degree of exertion, i.e. vigorous/intense, moderate, walking and average time spent sedentary during weekdays. Such studies have been conducted in Poland by Rozpara et al. [16], Korpak and Bergier [17], Panczyk [18], Bergier et al. [19] and Boruszczak and Urbaniak [20] as well as in other countries: Greece [21], Spain [22], Czech Republic [23], Norway [24], Latvia [25], Lithuania [26] and other Visegrad countries [27]. The results of the study by Rozpara et al. [16] on senior secondary school students from the Silesian region (province) for total physical activities were 2.976 MET in boys and 2.737 MET in girls, where vigorous levels of exertion in most boys $(50.0 \%)$ were greater than in girls $(30.0 \%)$. Most girls undertook low physical activities at 1.374 MET, whereas for boys this figure was 1.305 MET. Another study on senior secondary school students from Lublin [17] significantly showed much higher levels of physical activity, 7.378 MET in boys and 5.870 MET in girls, where high/vigorous levels were observed in $71.4 \%$ of boys and $54.2 \%$ of girls. Strikingly and surprisingly low levels of physical activity were found in a study on senior secondary school students in south-eastern Poland [18], with figures for boys ranging from 0.810 to $0.820 \mathrm{MET}$ and for girls from 0.730 to 0.820 MET. However, even a brief inspection of this study points up some serious shortcomings in the methodology by which this study was conducted, as were evidenced by very large differences in values of total physical activity. In contrast, extremely high figures for physical activities were measured in a study on 15-year-olds from rural and urban schools in the Greater-Poland (Wielkopolska) region [19]; MET values even greater than $12.000 \mathrm{MET}$ were observed, with most falling within the 4.001-8.000 and 8.001-12.000 MET ranges for $5.3 \%$ and $24 \%$ of students respectively. More rural (60\%) than urban (48\%) school students fell within the 4.001-8.000 range, with $17 \%$ of rural students achieving results of $4.000 \mathrm{MET}, 60 \%$ achieving $4.000-8.000$
MET, 18\% achieving 8.001-12.000 MET and 5\% achieving 12.001-16.000 MET. The breakdown of MET ranges for urban students was $22 \%$ at 4.000 MET, $48 \%$ at 4.001 8.000 MET, $30 \%$ at $8.001-12.000 \mathrm{MET}$ and $0 \%$ achieving over 12.000 MET. A further study of 16-18-year-olds in selected regions of Poland [20] found relatively low levels of physical activity, namely 2.640 MET in boys and 2.219 MET in girls. More male students undertook intense physical activities than female students, with the latter's activities mostly being at moderate levels, with no significant differences in physical activity being observed between places of residence. Considerable variations in physical activities were also found in the results of the short questionnaire version of IPAQ studies in different countries. In Greece, 12-17-year-olds [21] demonstrated (vigorous) physical activity levels of $6.260 \mathrm{MET}, 4.330$ MET (moderate), and 1.558 MET (low), while the figure for those of undefined age was 0.372 MET. In the 2010/11 school year in Spain, the daily levels of physical activity in 16-17-year-olds [22] were measured at $0.656 \mathrm{MET}$ in girls and 0.855 MET in boys, equivalent to weekly levels of 4.592 MET and 5.985 MET respectively. In addition, the study found that only half the student subjects undertook physical activity at the recommended levels considered to be health-promoting. A study of Latvian schoolchildren aged 16-18 years [25] demonstrated total physical activity at $2.963 \mathrm{MET}$, with boys showing significantly higher levels than girls, 3.124 MET and 2.790 MET respectively. These significant higher levels in boys were due to their engaging in vigorous exertions, whereas there were no such differences between the genders in terms of moderate and walking exertions/exercise. Walking in fact emerged as the most common type of physical activity in both boys and girls.

\section{THE FINDINGS FROM THE LONG PAQ QUESTIONNAIRE}

Studies in Poland based on this version show large variations in MET min/week results. A study performed on 18-year-olds, 140 boys and 130 girls from Cracow and Warsaw [28], showed very high levels of overall physical activity. At $13.488 \mathrm{MET}$, the boys showed significantly higher levels than the girls at 9.906 MET, where such activities were predominately undertaken at school, the least being done at home. The time taken up by sedentary activities during weekdays was 416.4 minutes in boys and 454.8 minutes for girls, whereas there were insignificant differences during weekends, with 288.3 minutes for boys and 341.3 minutes for girls. The same study revealed that male subjects from Warsaw's senior secondary schools [29] had even higher and significantly different values of 16.311 MET than girls at 10.590 MET, with physical activity in school time being the most common, accounting for $38.1 \%$ and $45.0 \%$ respectively, whereas the lowest percentage for both sexes in terms of sports activities was $14.5 \%$ and $13.0 \%$ respectively. Another study on physical 
activity in Canadian 6-19-year-olds [30] also showed that boys are more active than girls. Only $9 \%$ of boys and $4 \%$ of girls undertook 60 minutes worth of moderate-level or vigorous-level exercise at least 6 days a week. The daily number of footsteps was on average 12,100 in boys and 10,300 in girls. These young people spent 8.6 hours a day on sedentary activities, accounting for $62 \%$ of their time each day. A further Canadian study [30] measuring physical activity for 12-19-year-olds [30] involving walking and cycling showed that about half of the subjects (51.0\%) performed 1 to 5 hours of such activities per week but only $22.0 \%$ did so for more than 5 hours, with no gender differences observed with regard to walking. Subjects walking 1 to 5 hours a week had lower HDL levels and slimmer waistlines. However, $80.7 \%$ had not ridden bicycles within the past 3 months, with the remaining 19.3\% doing so for about 1 hour per week, with boys cycling 4 times more (15.6\%) than girls (4.1\%). Those subjects who had cycled for at least 1 hour a week had higher cardiovascular health benefits, lower BMI values, slimmer waistlines and better HDL results. Likewise, high levels of physical activity were found in studies of 15-17-yearolds from Upper Silesia [31] conducted between 2006 and 2008. Boys achieved overall physical activity levels of 10.531 MET, significantly higher than the girls at 8.099 MET. The main location where physical activity was undertaken in both girls and boys was at school, with significantly higher levels for boys. In terms of movement, sport and recreation, boys also showed higher levels than girls. When considering the mean intensity of exertion/ exercise, moderate levels were most frequently observed in both girls and boys, with significantly higher levels found in boys. There were however no significant gender differences in terms of high-intensity exertion or movement (walking). A study by Piatkowska [32] also assessed physical activity in 15-year-olds from 15 EU countries, where significant variations were seen in the levels of overall physical activity between different countries. In a ranking by activity, levels ranged from $23 \%$ in Sweden and $24 \%$ in France to $44 \%$ in the Netherlands and $40 \%$ in Germany. Poland achieved a middle ranking of $33.5 \%$, the European average being $31.3 \%$. The highest numbers of subjects reporting low levels of physical activity were from France (43.1\%) and Belgium (39.8\%), whilst the lowest were from the Netherlands (19.3\%) and Denmark (22.3\%), with Poland, at $27.9 \%$, occupying $12^{\text {th }}$ place out of the $17 \mathrm{EU}$ countries studied Other studies included adolescent subjects from Lithuania [26] and the Czech Republic [22], where Lithuanian 17-year-olds showed higher physical activities among boys at 4.895 MET than among girls at 4.404 MET, which was in line with other similar studies. These last mentioned studies also showed that higher self-reporting of physical fitness actually reflected higher physical activity levels in the subjects, especially for intensive/vigorous exertion. Adolescents aged 15-18 from the Czech Republic demonstrated wide variations in physical activity during these ages. MET levels for girls were 2.372, 3.742, 4.467 and 3.219 for those aged 15, 16, 17 and 18 respectively, which showed levels rising up to the age of 17 . The corresponding MET results for boys were 5.220, 4.270, 4.567 and 6.564 for those aged $15,16,17$ and 18 respectively, which may be regarded as representing a steady rise in physical activity. Research studies undertaken on a relatively large population of 15 to 17-year-olds in the Visegrad countries [29] also demonstrated significantly higher physical activity levels among boys compared to girls. Slovakian boys showed a MET value of 10.280, whilst girls showed a value of 7.287 MET. For the other countries the results were respectively as follows: 7.520 and 5.862 for Poland, 9.086 and 7.164 for the Czech Republic and 4.546 and 4.079 for Hungary. Overall, the levels of vigorous physical activity ranged $56.7 \%$ to $77.8 \%$ for boys and $42.4 \%$ to $67.4 \%$ for girls.

\section{EVALUATING PHYSICAL ACTIVITY BY MEANS OF AN ACCELEROMETER}

Results obtained using IPAQ, especially its longer questionnaire version, may overestimate subjective assessments [14], which is the reason why accelerometers are increasingly being used as supplementary assessments of physical activity. The review of a 2016 study conducted by Skender et al. [33] clearly demonstrated that this tool has ensured more consistent results for men, thereby encouraging the use of a combination of both these tools. Polish studies on 15-17-year-olds from Upper Silesia, involving the monitoring of weekly physical activities, were conducted by Groffik [31], using the ActiGraph tool to account for gender, days of the week, school days and weekend days. The recommended 700 footsteps per hour were achieved by boys for four days a week, and only one day a week by girls. The average number of footsteps per hour during school days was 693 for boys and 652 for girls, this difference being statistically insignificant. In assessing energy expenditure $\left(\mathrm{kcal}^{-\mathrm{kg}-\mathrm{hr}}\right)$ during school days, the differences found between the genders proved insignificant. It was however observed that boys more frequently take part in highintensity/vigorous and medium exertions (6-9 and 3-5.9 MET respectively) compared to girls. A U.S. study on two adolescent age groups [34] showed that boys were more physically active than girls, but that in both cases such activity dramatically declined between childhood and adolescence. Of those aged 6-11 years, $42 \%$ achieved the recommended 60 minutes worth of physical activity, whereas this fell to only $8 \%$ for 12 -19-year-olds. The study also found that those assessed by means of accelerometers achieved significantly lower physical activity scores compared to when levels were self-reported. It was also pointed out that any self-reporting of physical activity should be interpreted with great caution. Other U.S. studies using accelerometers on children aged 5-18 [35] have shown that watching TV for more than 5 hours 
a day is a major cause of obesity, and may also increase the risk of cardiovascular disease. An Iranian study on adolescents aged 9-18 [36] has further confirmed the commonly reported occurrence of physical activity being higher in boys than girls, where over half the boys (52.1\%) met the required recommendations on physical activity of 3 times a week, with only $9.8 \%$ of girls doing so. Those subjects most physically active were found to have lower fat mass. It should therefore be stressed that modern accelerometers are highly reliable instruments providing accurate measurements [37, 38].

\section{DISCUSSION}

There are many methods for assessing/measuring physical activity, making it very difficult to compare studies and to objectively determine any trends. In recent years, the IPAQ has been prepared in both short and long versions $[12,39]$. It has been previously indicated that the longer questionnaire version should be adopted in scientific studies that require given aspects of physical activities to be investigated in detail, such as at the workplace, during recreation and sports. The short version should be used for comparing physical activities of different populations within a given country or between different countries. A study in 2000 that was conducted in 12 countries and compared long and short questionnaire versions of the IPAQ showed no differences in reliability or accuracy [40]. In the present review, comparing long and short IPAQ questionnaire versions, it was found that physical activity is estimated more highly by the long version, as indeed already recognised in other studies [14, $15,40]$. It is therefore important that physical activity results should be compared when the same IPAQ version is used. The considerable variations in physical activity levels observed in the reviewed studies should alert future investigators in this area that their work needs be diligently prepared. In particular, it is the author's opinion that the tested duration of exertion required for any given physical exercise should be not be less than 10 minutes and that this should also be undertaken without any breaks. The intensity of any given activity should be precisely understood, which at a value of 8.0 will greatly impact on calculated MET results The now recognised merits of supplementing IPAQ-assessed physical activity with objective measurements using accelerometers should be acknowledged and taken into account. Indeed, they have already been so supplemented in Polish studies by Mynarski et al. [8] and Groffik [31], along with studies undertaken abroad $[29,30,36]$. By simultaneously applying both these methods, a much more objective assessment of physical activity levels can be accomplished.

\section{ACKNOWLEDGEMENTS}

Editors would like to acknowledge the invaluable assistance of Mr. Scott Thompson in the preparation of the final version of this article.

\section{DISCLOSURE}

Author reports no conflict of interest.

\section{References}

1. Drabik J, Resiak M. Styl życia w promocji zdrowia [Lifestyle in health promotion]. AWF, Gdańsk 2010.

2. Kimokoti RW, Newby PK, Gona P, et al. Diet quality, physical activity, smoking status, and weight fluctuation are associated with weight change in women and men. J Nutr 2010; 140: 1287-1293.

3. Lee IM, Shiroma EJ, Lobelo F, et al. Effect of physical inactivity on major non-communicable diseases worldwide: an analysis of burden of disease and life expectancy. Lancet 2012; 380: 219-229.

4. Corbin CB, Welk GJ, Corbin WR, et al. Kondycja, sprawność, zdrowie [Fitness, wellness and health]. Zysk i Spółka, Poznań 2007.

5. Jacobs RA, Lundby C. Mitochondria express enhanced quality as well as quantity in association with aerobic fitness across recreationally active individuals up to elite athletes. J Appl Physiol (1985) 2013; 114: 344-350.

6. Austin MW, Ploughman M, Glynn L, et al. Aerobic exercise effects on neuroprotection and brain repair following stroke: a systematic review and perspective. Neurosci Res 2014; 87: 8-15.

7. Drygas W, Kwasniewska M, Szczesniewska D, et al. Ocena poziomu aktywności fizycznej dorosłej populacji Polski. Wyniki programu WOBASZ [Assessment of phisical activity in Polish adults. WOBASZ program results]. Kardiol Pol 2005; 63: 636-640.

8. Mynarski W, Nawrocka A, Rozpara M, et al. Physical activity of male and female adolescents living in a town and a city in the context of public health recommendations. Biomedical Human Kinetics 2012; 4: 18-23.

9. Biernat E. Aktywność fizyczna mieszkańców Warszawy na przykładzie wybranych grup zawodowych [Phisical activity in Warsaw inhabitants in selected professional groups]. SGH, Warszawa 2011.

10. Wojtyła A, Kapka-Skrzypczak L, Paprzycki P, et al. Zachowania zdrowotne młodzieży. Raport [Health behavior in youth]. Instytut Medycyny Wsi, Lublin 2011.

11. Haskell WL, Lee I, Paite RR, et al. Physical activity and public health: Updated recommendation for adults from the American College of Sports Medicine and the American Heart Association. Med Sci Sports Exerc 2007; 39: 1423-1434.

12. Booth ML. Assessment of physical activity: an international perspective. Res Quart Exerc Sport 2000; 71: 114-120.

13. Biernat E, Stupnicki R. An overview of internationally applicable questionnaires designed for assessing physical activity. Phys Edu Sport 2005; 49: 61-73.

14. Biernat E. Physical Activity Questionaire - Polish long version. Polish J Sport Med 2013; 29: 1-5.

15. Wasilewska M. In search of the assessment of the physical activity level of the youth with the use of the IPAQ. Health Problems of Civilization 2017; 11: 15-22.

16. Rozpara M, Mynarski W, Czapla K. Szacowanie kosztu energetycznego aktywności fizycznej na podstawie badań kwestionariusza IPAQ [Energetic cost of physical activity based on IPAQ]. In: Teoretyczne i empiryczne zagadnienia rekreacji i turystyki [Theoretical and empirical issues of recreation and tourism]. Mynarski W (ed.). AWF, Katowice 2008. 
17. Korpak F, Bergier J. Aktywność fizyczna uczniów klas drugich I LO w Białej Podlaskiej [Physical activity in school children of second year in high school in Biala Podlaska]. Wychowanie Fizyczne i Zdrowotne 2011; 1: 20-25.

18. Pańczyk W. Aktywność fizyczna mieszkańców południowowschodnich regionów Polski u progu XXI wieku [Physical activity in South East Polish inhabitants in $20^{\text {th }}$ century]. In: Społeczno-edukacyjne oblicza współczesnego sportu i olimpizmu: aktywność fizyczna dzieci, młodzieży i dorosłych na przełomie XX i XXI wieku [Socio-educational faces of modern sport and olympics: activity physical children, adolescents and adults at the turn in $20^{\text {th }}$ and $21^{\text {st }}$ century]. Nowocień J, Chełmecki J (eds.). AWF, Warszawa 2010; 130-143.

19. Bergier B, Bergier J, Paprzycki P. Level and determinants of physical activity among school adolescents in Poland. Ann Agric Environ Med 2014; 21: 75-78.

20. Boruszczak K, Urbaniak Ł. Analiza porównawcza aktywności fizycznej uczniów miejskich i wiejskich na podstawie Międzynarodowego Kwestionariusza Aktywności Fizycznej (IPAQ) [Comperative analysis of activity physical in urban and rural students on the basis of IPAQ]. In: Środowisko społeczno-przyrodnicze a aktywność fizyczna człowieka [Social and natural environment and physical activity in humans]. Kaiser A, Sokołowski M (eds.). Wielkopolska Wyższa Szkoła Turystyki i Zarządzania, Poznań 2010.

21. Tsioufis C, Kyvelou S, Tsiachris D, et al. Relation between physical activity and blood pressure levels in young Greek adolescents: The Leontio Lyceum Study. Eur J Public Health 2011; 21: 63-68.

22. Cocca A, Liukkonen J, Mayorga-Vega D, et al. Health-related physical activity levels in Spanish youth and young adults. Percept Mot Skills 2014; 118: 247-260.

23. Kudláček M. Increase of the effectiveness of school PE classes through sport preferences survey: Contextual prediction of demanded sport activities. Acta Univ Palacki Olomuc Gymn 2013; 43: 42-48

24. Rangul V, Holmen TL, Kurtze N, et al. Reliability and validity of two frequently used self-administered physical activity questionnaires in adolescents. BMC Med Res Methodol 2008; 8: 47-57.

25. Ignatjeva A, Bergier J. Nutritional habits and physical activity of the youth of Latvia considering gender differences. Health Problems of Civilization 2016; 10: 25-34.

26. Bergier B, Bergier J, Wojtyła A. Various aspects of physical activity among Lithuanian adolescents. Ann Agric Environ Med 2012 19: 775-779.

27. Ács P, Bergier J, Salonna F, et al. Gender differences in physical activity among secondary school students in the Visegrad countries (V4). Health Problems of Civilization 2016; 10: 21-29.

28. Piątkowska M, Pec K, Pec T. Aktywność fizyczna młodzieży $\mathrm{w}$ wieku ponadgimnazjalnym [Psychical activity of upper secondary students]. Wychowanie Fizyczne i Zdrowotne 2007; 8: 30-33.

29. Colley C, Garriguet D, Janssen I, et al. Physical activity of Canadian children and youth: Accelerometer results from the 2007 to 2009 Canadian Health Measures Survey. Health Rep 2011; 22:15-23.

30. Larouche R, Faulkner GE, Fortier M, et al. Active transportation and adolescents' health: the Canadian Health Measures Survey. Am J Prev Med 2014; 46: 507-515.
31. Groffik D. Struktura aktywności fizycznej młodzieży 15-17letniej Górnego Śląska [Pattern of physical activity in youth age 15-17 in Upper Silesia]. Akademia Wychowania Fizycznego w Katowicach, Katowice 2015.

32. Piątkowska M. Uczestnictwo Polaków w aktywności fizycznej w porównaniu do innych krajów Unii Europejskiej [Participation of Poles in physical activity compared to other EU countries]. In: Współczesne metody badań aktywności, sprawności i wydolności fizycznej człowieka [Modern methods of studying people's activity, dexterity and fitness]. Buśko K, Charzewska J, Kaczanowski K (eds.). AWF, Warszawa 2010.

33. Skender S, Ose J, Chang-Claude J, et al. Akcelerometry and physical activity questionaires - a systematic review. BMC Public Health 2016; 16: 515.

34. Troiano RP, Berrigan D, Dodd KW, et al. Physical activity in the United States measured by accelerometer. Med Sci Sports Exerc 2008; 40: 181-188.

35. Staiano AE, Harrington DM, Broyles ST, et al. Television, adiposity, and cardiometabolic risk in children and adolescents. Am J Prev Med 2013; 44: 40-47.

36. Jeddi M, Dabbaghmanesh MH, Ranjbar Omrani G, et al. Body composition reference percentiles of healthy Iranian children and adolescents in southern Iran. Arch Iran Med 2014; 17: 661-669.

37. Eisenmann JC, Strath SJ, Shadrick D, et al. Validity of uniaxial accelerometry during activities of daily living in children. Eur J Appl Physiol 2004; 91: 259-263.

38. Rothney MP, Schaefer EV, Neumann MM, et al. Validity of physical activity intensity predictions by Acti Graph, Actical, and RT3 accelerometers. Obesity (Silver Spring) 2008; 16: 1946-1952.

39. Craig CL, Marshall AL, Sjöström M, et al. International Physical Questionnaire: 12-country reliability and validity. Med Sci Sport Exerc 2003; 35: 1381-1395.

40. Gajewski K, Biernat E. Zastosowanie Międzynarodowego Kwestionariusza Aktywności Fizycznej (IPAQ) - Za i przeciw, czyli kilka rozważań metodycznych i ich konsekwencje [Application of the International Questionnaire Physical Activity (IPAQ) - pros and cons, a few methodical considerations and their consequences]. In: Współczesne metody badań aktywności, sprawności i wydolności fizycznej człowieka [Modern methods for testing activity, fitness and physical fitness human]. Buśko K, Charzewska J, Kaczanowski K (eds.). AWF, Warszawa 2010. 